\title{
A randomized controlled trial of daclizumab versus anti-thymocyte globulin induction for heart transplantation
}

\author{
John C Mullen ${ }^{1,2^{*}}$, Emily J Kuurstra', Antigone Oreopoulos ${ }^{1}$, Michael J Bentley ${ }^{1}$ and Shaohua Wang ${ }^{1}$
}

\begin{abstract}
Background: The purpose of this study was to test the efficacy and safety of daclizumab (DZM) versus anti-thymocyte globulin (ATG) as a component of induction therapy in heart transplant recipients.

Methods: Thirty heart transplant patients were randomized to receive either ATG or DZM during induction therapy. Patients in the DZM group received an initial dose of $2 \mathrm{mg} / \mathrm{kg}$ intravenous (IV) at the time of transplant and $1 \mathrm{mg} / \mathrm{kg}$ IV on postoperative day 4.

Discussion: Recipient, donor, and intraoperative variables did not differ significantly between groups. The cost of induction therapy, total drug cost, and hospital ward costs were significantly less for the DZM group. Average absolute lymphocyte and platelet counts were significantly higher in the DZM group. There were no significant differences in the incidence of rejection, infection, malignancy, or steroid-induced diabetes. One year survival was excellent in both groups $(87 \%, P=0.1)$. Daclizumab is a safe component of induction therapy in heart transplantation.
\end{abstract}

Keywords: Heart transplantation, Induction therapy, Immunosuppression, Daclizumab, Anti-thymocyte globulin

\section{Background}

Cardiac transplantation remains a definitive treatment option for patients with end-stage heart disease. Survival rates have improved dramatically. Nonetheless, progress in immunosuppression has been slower, partly because the heart is a fundamental organ and acute allograft rejection can include hemodynamic compromise, irreversible graft injury, and death. Furthermore, the immunosuppressive therapy used to prevent rejection increases the risk of infection, which continues to be a leading cause of death in the first year after cardiac transplantation [1,2]. A common immunosuppression protocol for cardiac transplantation includes cyclosporine, mycophenolate mofetil, and corticosteroids (triple therapy). An alternative to standard triple therapy at the time of cardiac transplantation has been the use of augmented immunosuppression, commonly termed 'induction therapy'. Induction agents consist of antibodies that exhibit protective effects

\footnotetext{
* Correspondence: jmullen@ualberta.ca

'Division of Cardiac Surgery, University of Alberta Hospital, Edmonton, AB, Canada

${ }^{2}$ Division of Cardiac Surgery, University of Alberta Hospital, 2D2.18 WMC, 8440112 Street, Edmonton, AB T6G 2B7, Canada
}

from allograft rejection; they are administered during the immediate postoperative period when the risk of rejection is highest due to a high donor leukocyte load [3]. Data from the International Society of Heart and Lung Transplant (ISHLT) show that $47 \%$ of adult heart transplant patients in the first 6 months of 2012 received some type of induction therapy [1]. Either a polyclonal anti-lymphocyte/anti-thymocyte globulin or an interleukin-2 (IL-2) receptor antagonist was utilized in most protocols; however, the type of product used, its dosage, and the duration of administration varied greatly. At present, there is no general consensus on the best method of induction. This fact has prompted the development of new immunosuppressive agents designed to reduce the incidence of acute rejection.

Daclizumab (DZM) is a novel compound for use as a component of induction therapy. This agent is a murine monoclonal antibody, directed at the alpha subunit of the interleukin-2 receptor (IL-2R) expressed on activated T-lymphocytes [4]. Ninety percent of the murine protein structures have been replaced with human amino acid sequences through genetic engineering. It therefore does not induce a clinically relevant response by the host 
immune system. DZM was approved by Health Canada and the Federal Drug Administration (FDA) for prophylactic use of acute organ rejection in patients receiving renal transplants. Our induction therapy included Tlymphocyte inactivation through the administration of polyclonal anti-thymocyte globulin (ATG). There have been no reported randomized controlled trials comparing DZM to ATG induction in heart transplantation. The purpose of this study was to compare these therapies in heart transplant recipients.

\section{Methods}

All adults listed for heart transplantation between June 2001 and April 2005 were considered for the study. Exclusion criteria included emergent surgery, previous transplant, multiple-organ transplant including heartlung transplant, active infection, hepatitis $C$, high positive panel reactive antibodies ( $>15 \%)$, known sensitivity to DZM, ATG, or mouse antigens, expected inability to be followed at the study center for a full year, and inability to give informed consent. Ethical approval was obtained from the University of Alberta Health Research Ethics Board.

A total of 30 adult heart transplant recipients were randomized to receive either DZM (Hoffman-La Roche Ltd., ON, Canada) or ATG (Pharmacia \& Upjohn Inc., ON, Canada) as part of induction therapy. Randomization was generated by computer. Enrolment and assessment of outcomes were performed by two research assistants. Only patients were blinded to the treatment. The primary endpoints of this study were the number and severity of infection episodes post-transplant. Secondary endpoints included incidence of rejection, survival, and cost.

\section{Immunosuppressive regimen}

Patients in the control group received $10 \mathrm{mg} / \mathrm{kg}$ intravenous (IV) ATG beginning postoperatively and infused continuously for 5 to 7 days until cyclosporine or tacrolimus reached therapeutic levels. Patients in the treatment group received DZM IV at $2 \mathrm{mg} / \mathrm{kg}$ within $4 \mathrm{~h}$ postoperatively followed by a single $1 \mathrm{mg} / \mathrm{kg}$ dose on postoperative day 4. Patients in both groups received methylprednisolone (Solu-Medrol ${ }^{\circ}$, Novopharm, ON, Canada) $1 \mathrm{~g}$ IV intraoperatively, followed postoperatively by $2 \mathrm{mg} / \mathrm{kg}$ IV every $12 \mathrm{~h}$ for three doses. This was followed by prednisone or methylprednisolone (depending on whether the patient could tolerate oral medication) $1 \mathrm{mg} / \mathrm{kg}$ daily. This was tapered by $2 \mathrm{mg} /$ day to 0.3 $\mathrm{mg} / \mathrm{kg} /$ day. Mycophenolate mofetil (CellCept ${ }^{\oplus}$, Hoffman La-Roche, ON, Canada) was given preoperatively 1,000 mg per oral or IV followed by $1,000 \mathrm{mg}$ IV twice daily postoperatively until the patient could tolerate oral medication. At this time the patient was switched to mycophenolate mofetil 1,000 mg per oral twice daily, with a target dose of $3 \mathrm{~g}$ daily. Patients treated with cyclosporine received cyclosporin A (Neoral ${ }^{\circ}$, Novartis Pharmaceuticals Canada Inc., QB, Canada) $150 \mathrm{mg}$ to $300 \mathrm{mg}$ per oral twice daily until therapeutic levels were reached $(250 \mu \mathrm{g} / \mathrm{L}$ to $400 \mu \mathrm{g} / \mathrm{L}$ ). Patients treated with tacrolimus (Prograf ${ }^{\oplus}$, Astellas Pharma Canada, Inc., ON, Canada) received tacrolimus $2 \mathrm{mg}$ to $5 \mathrm{mg}$ per oral twice daily until therapeutic levels were reached $(10 \mathrm{mg} / \mathrm{mL}$ to $15 \mathrm{mg} / \mathrm{mL})$. Patients in the ATG group received a pulse of methylprednisolone $2 \mathrm{mg} / \mathrm{kg}$ IV every $12 \mathrm{~h}$ for three doses starting at the point of ATG discontinuation.

\section{Infection prophylaxis}

Patients with Epstein-Barr virus (EBV) or cytomegalovirus (CMV) donor-seropositive/recipient-seronegative received $900 \mathrm{mg}$ each day for 14 weeks of oral ganciclovir (Cytovene ${ }^{\oplus}$, Hoffman-La Roche Ltd., ON, Canada) or valgancyclovir (Valcyte ${ }^{\circledR}$ Hoffman-La Roche Ltd, ON, Canada) therapy. Patients who were CMV donor seropositive/recipient seropositive or donor seronegative/ recipient seropositive received 2 weeks of $900 \mathrm{mg}$ twice per day of oral ganciclovir or valganciclovir therapy.

\section{Diagnosis and treatment of acute and chronic rejection}

Acute rejection was defined as either biopsy-proven as defined by ISHLT grade 3R (3A or 3B) or higher histology [5], suspected and subsequently treated rejection in the presence of hemodynamic compromise, or grade $1 \mathrm{~A}$ or $1 \mathrm{~B}$ with symptoms (reduced ejection fraction, shortness of breath, decreased voltages or a gallop rhythm). Treatment of acute rejection typically consisted of intravenous methylprednisolone $500 \mathrm{~g}$ to $1,000 \mathrm{~g}$ for 3 days. Severe high grade or humoral rejection was treated with plasmaphoresis, intravenous immune globulin, ATG, or RATGAM (ATG made from rabbits). Grade 2 rejection or symptomatic low grade (1A or $1 \mathrm{~B})$ rejection was treated with a $50 \mathrm{mg}$ to $80 \mathrm{mg}$ prednisone tapering dose. Heart transplant patients at our centre receive 13 biopsies during the first year post transplant.

\section{Diagnosis of infection}

Infection was considered significant if it resulted in symptoms and/or a change in medical management. An infection was also considered to be severe if it appeared to prolong hospitalization, required re-admission to hospital, or was treated with intravenous antibiotics after initial hospitalization.

\section{Cost analysis}

Cost data were determined by calculating total drug cost, ICU cost, and ward cost. Drug costs were obtained directly from the pharmacy department. ICU and ward costs were based on a study by Hamilton et al. [6], in which hospital costs were acquired from patient 
resource consumption profiles. This accounting method was developed at our center. It included nursing costs, the direct and indirect labor and supply costs related to nursing, laboratory, radiological, and rehabilitative medicine costs, and all direct and indirect labor and supply costs required to perform tests or procedures. Physician fees were not included.

\section{Statistics}

Statistical analysis was performed using SPSS software (SPSS Inc., Chicago, IL, USA). All analysis was based upon an intention to treat principle. Continuous variables were compared between groups by an independent $t$-test or Mann-Whitney $U$ where non-parametric analysis was appropriate. Discrete variables were compared between groups using chi-squared and Fisher's exact tests where appropriate. Survival curves were created with the Kaplan-Meier method with log-rank comparisons between groups. Results of continuous variables are presented as mean \pm standard error. The alpha level was set at $P \leq 0.05$. A study by Sarris et al. [7] revealed a 73\% 1 -year infection rate in heart transplant recipients. A sample size of 14 patients per group was determined to detect a $43 \%$ reduction in infection rate with an alpha error of $5 \%$ and a power of $80 \%$.

\section{Results}

The flow of participants through the study is presented in Figure 1. One hundred and ninety-nine patients were assessed for eligibility: 130 were deemed ineligible due to exclusion criteria, seven declined, 32 did not participate because they did not receive a transplant during the study period, and the remaining 30 were randomized. There were no drop-outs.

A summary of recipient demographics and perioperative outcomes are presented in Table 1. There were no significant differences in preoperative recipient demographics. The incidence of cytomegalovirus (CMV) and Epstein-Barr virus (EBV) mismatch was similar between groups. Patients in the DZM group tended to require more inotropic support postoperatively (higher inotropic severity score: DZM $65 \pm 5$, ATG $49 \pm 6, P=0.07)$. No other statistically significant differences were observed in intraoperative and immediate postoperative outcomes.

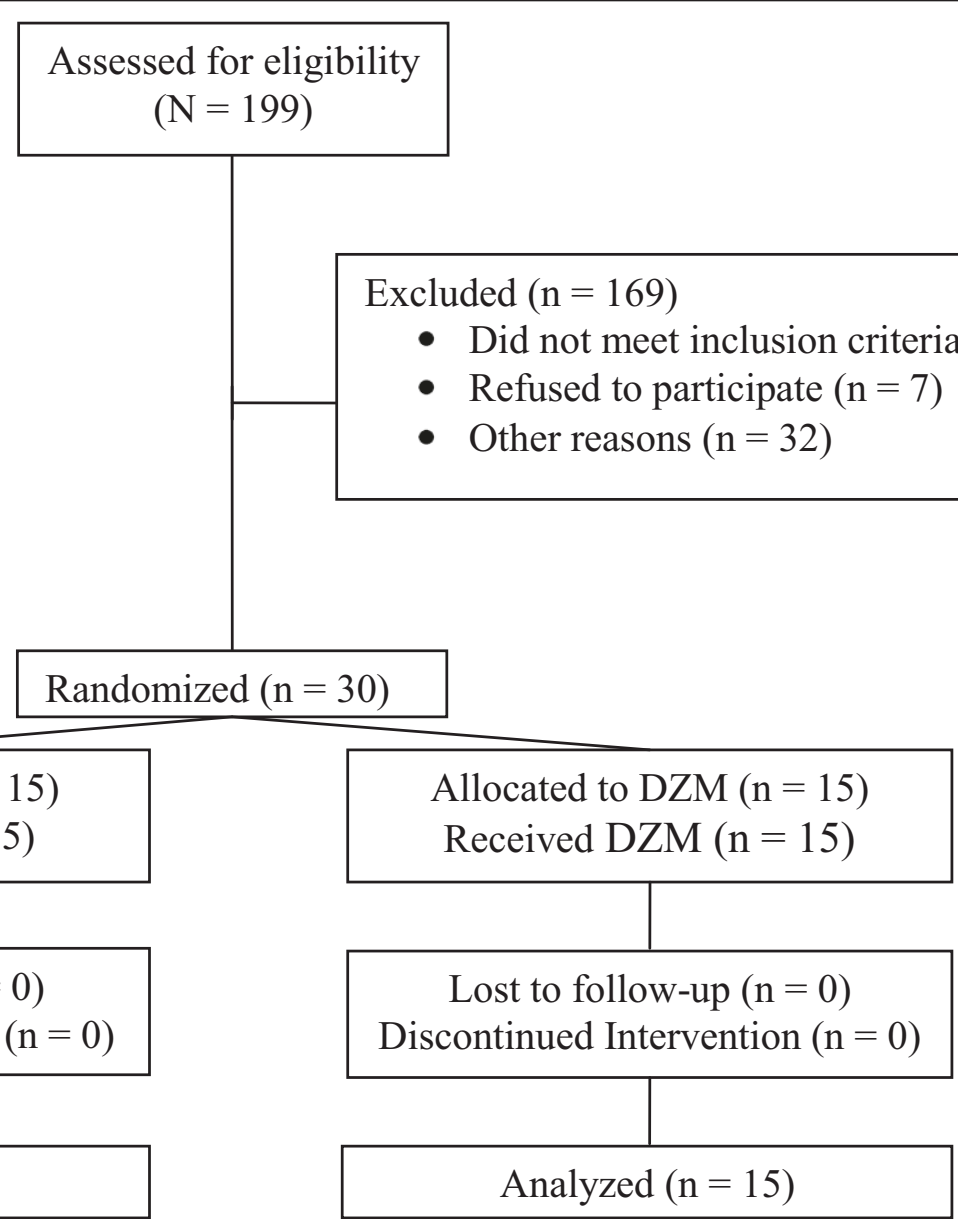

Figure 1 CONSORT diagram. 
Table 1 Recipient demographics and perioperative outcomes

\begin{tabular}{|c|c|c|c|}
\hline & $\begin{array}{l}\text { ATG } \\
(n=15)\end{array}$ & $\begin{array}{l}\text { DZM } \\
(n=15)\end{array}$ & $P$ value \\
\hline Age (years) & $58 \pm 3$ & $57 \pm 3$ & 0.9 \\
\hline Sex (male/female) & $11 / 4$ & $12 / 3$ & 1.0 \\
\hline \multicolumn{4}{|l|}{ Diagnosis } \\
\hline Idiopathic cardiomyopathy & $11(73 \%)$ & $10(67 \%)$ & 1.0 \\
\hline Other & $4(27 \%)$ & $5(33 \%)$ & 1.0 \\
\hline Height (cm) & $172 \pm 2$ & $172 \pm 3$ & 0.9 \\
\hline Weight (kg) & $78 \pm 3$ & $83 \pm 5$ & 0.4 \\
\hline Body mass index $\left(\mathrm{kg} / \mathrm{m}^{2}\right)$ & $26 \pm 1$ & $28 \pm 2$ & 0.4 \\
\hline \multicolumn{4}{|l|}{ Status } \\
\hline 1: Stable and waiting out of hospital & $8(53 \%)$ & $9(60 \%)$ & 1.0 \\
\hline 2: Stable and waiting in hospital & $3(20 \%)$ & $2(13 \%)$ & 1.0 \\
\hline 3: In hospital on Inotropic support & $4(27 \%)$ & $3(20 \%)$ & 1.0 \\
\hline 4: Intubated & $0(0 \%)$ & $1(7 \%)$ & 1.0 \\
\hline Diabetes mellitus & $0(0 \%)$ & $2(13 \%)$ & 0.5 \\
\hline \multicolumn{4}{|l|}{ Lymphocytotoxic crossmatch } \\
\hline Negative & $15(100 \%)$ & $15(100 \%)$ & 1.0 \\
\hline \multicolumn{4}{|l|}{ CMV mismatch } \\
\hline Negative recipient/Positive donor & $1(7 \%)$ & $1(7 \%)$ & 1.0 \\
\hline \multicolumn{4}{|l|}{ EBV mismatch } \\
\hline Negative recipient/Positive donor & $0(0 \%)$ & $0(0 \%)$ & - \\
\hline Operative time (min) & $333 \pm 18$ & $351 \pm 20$ & 0.5 \\
\hline Cardiopulmonary bypass time (min) & $187 \pm 10$ & $194 \pm 16$ & 0.7 \\
\hline Intubation time (h) & $96 \pm 47$ & $130 \pm 55$ & 0.7 \\
\hline Intensive care unit time (h) & $264 \pm 102$ & $289 \pm 96$ & 0.9 \\
\hline Inotropic severity score & $49 \pm 6$ & $65 \pm 5$ & 0.07 \\
\hline Total hospital length of stay (days) & $29 \pm 8$ & $26 \pm 6$ & 0.8 \\
\hline
\end{tabular}

CMV: cytomegalovirus; EBV: Epstein-Barr virus.

There were also no significant differences in donor demographics between groups (Table 2).

Postoperative laboratory and drug administration values averaged over a 10-day post-transplant period are presented in Table 3. Average absolute lymphocyte counts were significantly higher in the DZM group $\left(0.89 \times 10^{9} / \mathrm{L}\right.$

Table 2 Donor characteristics

\begin{tabular}{llll}
\hline & ATG $(\boldsymbol{n}=\mathbf{1 5})$ & DZM $(\boldsymbol{n}=\mathbf{1 5})$ & $\boldsymbol{P}$ value \\
\hline Age (years) & $35 \pm 5$ & $35 \pm 4$ & 0.9 \\
Sex (male/female) & $11 / 4$ & $10 / 5$ & 1.0 \\
Height $(\mathrm{cm})$ & $172 \pm 3$ & $172 \pm 3$ & 0.9 \\
Weight $(\mathrm{kg})$ & $78 \pm 5$ & $86 \pm 4$ & 0.2 \\
Body mass index $\left(\mathrm{kg} / \mathrm{m}^{2}\right)$ & $26 \pm 1$ & $29 \pm 1$ & 0.1 \\
Donor/recipient weight ratio & $1.01 \pm 0.05$ & $1.08 \pm 0.09$ & 0.5 \\
Donor ischemic time (min) & $254 \pm 22$ & $249 \pm 24$ & 0.9 \\
\hline
\end{tabular}

vs. $\left.0.45 \times 10^{9} / \mathrm{L}, P<0.0001\right)$, as well as average platelet count (153 per $\mathrm{mm}^{3}$ vs. 114 per $\left.\mathrm{mm}^{3}, P=0.004\right)$. In addition, average chloride was higher in the DZM group $(103 \pm 1 \mathrm{mmol} / \mathrm{L} v s .101 \pm 1 \mathrm{mmol} / \mathrm{L}, P=0.05)$. In the control group, ATG was infused for $7 \pm 2$ days. As expected, volume of ATG given intravenously was significantly higher than DZM $(5,934 \pm 669 \mathrm{~mL}$ vs. $942 \pm 152$ $\mathrm{mL}, P<0.0001)$, and methylprednisolone dose was significantly less in the DZM group $(495 \pm 38 \mathrm{mg} v s .1,242 \pm$ $278 \mathrm{mg}, P<0.0001)$. Other drug dosages and volumes were similar between groups.

The cost analysis is illustrated in Figure 2. Induction cost (cost of DZM vs. cost of ATG) was significantly lower in the DZM group (Figure 2, $\$ 5,337 \pm 308, \mathrm{CI} \pm$ 604.17 vs. $\$ 7,384 \pm 799$, CI $\pm 1,565.84, P=0.03)$. Total drug cost (induction cost plus methylprednisolone, mycophenalate mofetil, cyclosporine A and/or tacrolimus, and prednisone) was also significantly lower in the DZM group (Figure 2, $\$ 6,044 \pm 328, \mathrm{CI} \pm 642.28$ vs. $\$ 8,133 \pm$ 828 , $\mathrm{CI} \pm 1,622.97, P=0.03)$. In addition, hospital ward (step-down unit) cost was lower in the DZM group (Figure 2, $\$ 11,353 \pm 3,320, \mathrm{CI} \pm 6,507.38$ vs. $\$ 14,376 \pm$ $3,526, \mathrm{CI} \pm 6,911.53, P<0.05)$. Intensive care unit stay and total hospital costs were not significantly different between groups (Figure 2).

The incidence of rejection is presented in Table 4 . Mean biopsy grade was lower in the DZM group, but not statistically different $(0.3 v s .0 .4, P=0.09)$. Allograft rejection occurred in two patients, both in the ATG group. One of these patients had confirmed humoral rejection 19 days post transplant, and was treated with IV immune globulin. The second patient experienced an episode of hypotension 6 days post transplant with right ventricular dysfunction and right bundle branch block with decreased voltages. This was felt to be due to acute rejection, and the patient was subsequently treated with pentaspan, inotropes, IV cyclosporine A, and pulse steroids.

The number of patients experiencing at least one episode of infection was the same between groups (Table 4, $67 \%$ in both groups). Time to first infection and other infectious complications were also similar between the two groups.

No patient had any acute side effect or allergic reaction to either study drug. There was no significant difference for incidence of steroid induced-diabetes. None of the study patients were re-transplanted. One of the patients in the DZM group had an incidence of malignancy: a basal cell carcinoma lesion on the ear which was treated successfully.

An actuarial survival curve is presented in Figure 3. Survival at 1 month and 1 year was $100 \%$ and $87 \%$ in the DZM group, and $93 \%$ and $87 \%$ in the ATG group, respectively. There were two patients who died in the ATG group. The first patient in the ATG group died 5 
Table 3 Postoperative laboratory data and drug administration

\begin{tabular}{|c|c|c|c|}
\hline & ATG $(n=15)$ & DZM $(n=15)$ & $\mathrm{p}$ value \\
\hline Average white blood cells $\left(\times 10^{9} / \mathrm{L}\right)$ & $16.6 \pm 1.3$ & $16.4 \pm 1.2$ & 0.9 \\
\hline Average neutrophils $\left(\times 10^{9} / \mathrm{L}\right)$ & $13.9 \pm 1.0$ & $13.8 \pm 0.9$ & 0.9 \\
\hline Average absolute lymphocytes $\left(\times 10^{9} / \mathrm{L}\right)$ & $0.45 \pm 0.04$ & $0.89 \pm 0.09$ & $<0.0001$ \\
\hline Average red blood cells $\left(\times 10^{9} / \mathrm{L}\right)$ & $3.3 \pm 0.1$ & $3.2 \pm 0.1$ & 0.2 \\
\hline Average platelet count (per $\mathrm{mm}^{3}$ ) & $114 \pm 9$ & $153 \pm 8$ & 0.004 \\
\hline Average hemoglobin $(\mathrm{g} / \mathrm{L})$ & $10.3 \pm 0.2$ & $9.9 \pm 0.2$ & 0.2 \\
\hline Average sodium (mmol/L) & $136 \pm 1$ & $137 \pm 1$ & 0.6 \\
\hline Average potassium (mmol/L) & $4.2 \pm 0.1$ & $4.2 \pm 0.1$ & 0.7 \\
\hline Average chloride $(\mathrm{mmol} / \mathrm{L})$ & $101 \pm 1$ & $103 \pm 1$ & 0.05 \\
\hline Average $\mathrm{CO}_{2}(\mathrm{mmol} / \mathrm{L})$ & $25 \pm 1$ & $24 \pm 1$ & 0.2 \\
\hline Average glucose (mmol/L) & $8.4 \pm 0.4$ & $8.7 \pm 0.7$ & 0.6 \\
\hline Average urea (mmol/L) & $16.2 \pm 1.3$ & $16.8 \pm 1.2$ & 0.7 \\
\hline Average ionized calcium (mmol/L) & $1.25 \pm 0.21$ & $1.16 \pm 0.02$ & 0.09 \\
\hline Average creatinine (mmol/L) & $143 \pm 10$ & $178 \pm 21$ & 0.1 \\
\hline Platelet units given & $8 \pm 2$ & $7 \pm 4$ & 0.9 \\
\hline Red blood cell units given & $9 \pm 2$ & $8 \pm 3$ & 0.8 \\
\hline Study drug induction volume $(\mathrm{mL})$ & $5,934 \pm 669$ & $942 \pm 152$ & $<0.0001$ \\
\hline Methylprednisolone (mg) & $1,242 \pm 278$ & $495 \pm 38$ & $<0.0001$ \\
\hline Prednisone (mg) & $552 \pm 38$ & $626 \pm 53$ & 0.2 \\
\hline IV Mycophenolate Mofetil (mg) & $6,017 \pm 788$ & $6,000 \pm 1005$ & 1.0 \\
\hline p.o. Mycophenolate Mofetil (mg) & $14,983 \pm 1025$ & $16,317 \pm 1145$ & 0.4 \\
\hline Patients receiving cyclosporin A only & 12 & 11 & 1.0 \\
\hline Patients receiving tacrolimus only & 2 & 1 & 1.0 \\
\hline Patients converted from cyclosporin A to tacrolimus & 0 & 3 & 0.2 \\
\hline Patients converted from tacrolimus to cyclosporin A & 1 & 0 & 1.0 \\
\hline Cyclosporin A (mg) & $2,532 \pm 348$ & $2,621 \pm 333$ & 0.8 \\
\hline Tacrolimus (mg) & $40 \pm 14$ & $40 \pm 6$ & 1.0 \\
\hline Insulin (units) & $502 \pm 80$ & $724 \pm 202$ & 0.3 \\
\hline Total steroids for 1 year (mg) & $4,631 \pm 638$ & $3,846 \pm 434$ & 0.2 \\
\hline
\end{tabular}

days post transplant due to intestinal ischemia. The second patient in the ATG group died 49 days post transplant due to fungal sepsis. Two patients also died in the DZM group. The first patient died 72 days post transplant due to sepsis. The second patient in the DZM group died 267 days post transplant of a stroke.

\section{Discussion}

Infection and rejection have been identified as risk factors for morbidity and mortality after heart transplantation [1]. In order to improve patient survival and quality of life, strategies have been developed to minimize these risk factors for infection and rejection, including induction agents as part of the immunosuppression regimen in the early postoperative period. This study compared the results of using DZM versus ATG during induction therapy after heart transplantation.
The use of DZM in addition to a triple immunosuppressive regimen was well tolerated in heart transplant recipients, with one adverse reaction to the drug. There were no differences in the incidence of rejection, steroidinduced diabetes or malignancy compared to patients who received ATG. In addition, average absolute lymphocytes and average platelet count were significantly higher in the DZM group. One-year survival was excellent in both groups (87\%) and was similar to the experience from the ISHLT Data Registry (1-year survival $81 \%$ based on survival rates for heart transplants performed between 1982 and 2011 [1].

The efficacy and safety of DZM has been demonstrated in a large number of kidney [8-28], kidneypancreas [29,30], liver [31-36], and lung clinical trials $[37,38]$. There have been few studies involving DZM in cardiac transplantation [39-45], despite the observation 


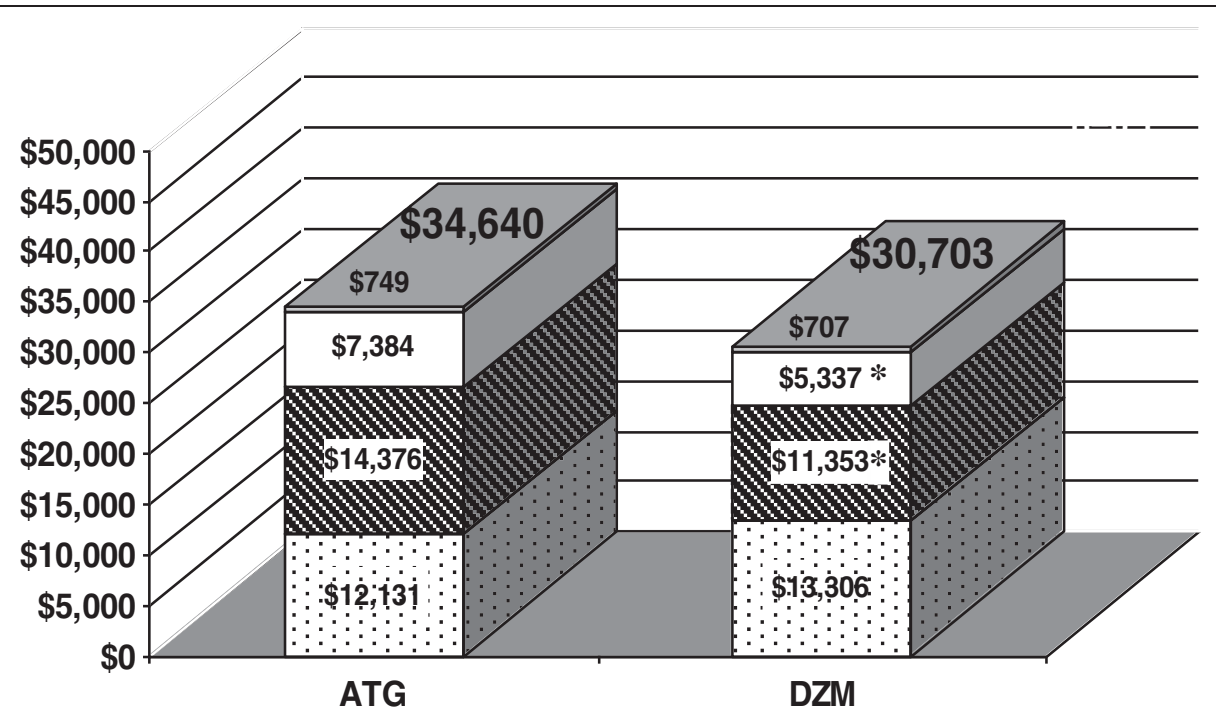

\section{$\square$ ICU $\mathbf{Q}$ Ward $\square$ Study Drug $\square$ Other Immunosuppression}

* Denotes significant difference $(\mathrm{p}<0.05)$ in costs between ATG and DZM groups

Figure 2 Cost analysis: total hospital cost $(P=0.8)$.

that almost $50 \%$ of patients undergoing cardiac transplantation receive anti-body-based induction therapy [1].

In our previous study of ATG and DZM in lung transplant recipients [37], both agents were also equally effective in rejection outcomes, however, the time to first

Table 4 Rejection, infection, and other outcomes

\begin{tabular}{llll}
\hline & $\begin{array}{l}\text { ATG } \\
(\mathbf{n = 1 5 )}\end{array}$ & $\begin{array}{l}\text { DZM } \\
(\mathbf{n = 1 5 )}\end{array}$ & p value \\
\hline Mean biopsy grade & 0.4 & 0.3 & 0.09 \\
Patients experiencing rejection & $2(13 \%)$ & 0 & 0.5 \\
Total number of acute rejections & 2 & 0 & 0.2 \\
Time to first rejection episode (days) & 84 & - & - \\
Patients experiencing infection & $10(67 \%)$ & $10(67 \%)$ & 1.0 \\
Total number of infections & 25 & 21 & 0.7 \\
Infections/patient & 1.7 & 1.4 & 0.7 \\
Patients experiencing severe infection & $4(27 \%)$ & $5(33 \%)$ & 1.0 \\
Number of severe infections & 7 & 7 & 1.0 \\
Severe infections/patient & 0.5 & 0.5 & 1.0 \\
Number of CMV infections & 1 & 2 & 1.0 \\
Malignancy & 0 & 1 & 1.0 \\
Steroid-induced diabetes & 2 & 2 & 1.0 \\
Re-transplant & 0 & 0 & - \\
ICU length of stay (days) & $11 \pm 4$ & $12 \pm 4$ & 09 \\
Total hospital length of stay (days) & $29 \pm 8$ & $27 \pm 6$ & 0.8 \\
One-month survival & $93 \%$ & $100 \%$ & 0.1 \\
One-year survival & $87 \%$ & 0.1 \\
\hline & & & -1.0 \\
\hline
\end{tabular}

rejection tended to be more prolonged with DZM (ATG: 138 days, DZM: 220 days, $P=0.06$ ).

The incidence of overall infection in the present study is similar to other reports in heart transplantation [7]. DZM has not been found to alter infection rates in kidney $[9,12,15,21,23,46]$, kidney-pancreas [28-30], heart [42,45], lung $[37,38,47,48]$ or liver $[31,34,35,49,50]$ transplant recipients.

The results of this study support the efficacy of a two dose DZM regimen which is simpler in that patients need not return to hospital for treatment every 2 weeks. The ATG regimen is more complex than our DZM regimen, requiring 5 to 7 days of continuous intravenous infusion and more steroid administration. In addition, ATG may have limited use due to the formation of antibodies; therefore, treatment of future rejection episodes may not be possible with ATG.

In this study, both average absolute lymphocyte count and platelet count were significantly reduced in the ATG group compared to the DZM group (Table 3). This finding is consistent with our previous study of the two agents in lung transplant recipients [37]. Brock and colleagues [38] noted that in lung transplantation, patients receiving ATG induction most commonly develop thrombocytopenia, with $74 \%$ developing a platelet count of $<100,000 / \mathrm{mm}^{3}$ [38]. In our current study, one patient in the ATG group developed severe thrombocytopenia, however, not in response to the ATG infusion.

The exact mechanism of effect of DZM is unknown; however, the efficacy of DZM is likely related to its selective targeting of active T-lymphocytes. DZM readily 


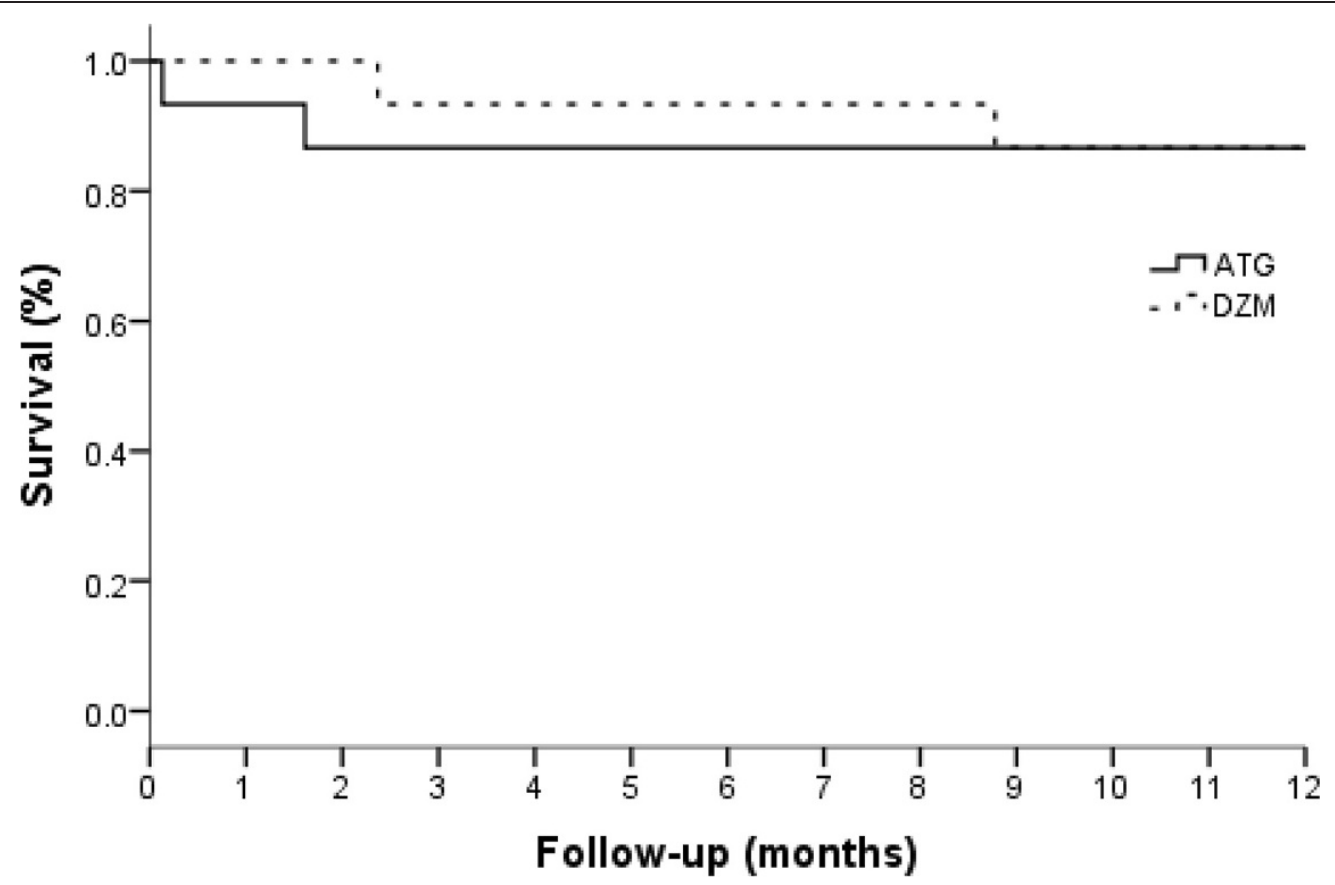

Figure 3 Actuarial survival. Log rank comparison, $P=0.1$.

binds to the alpha subunit of the IL-2 receptor of circulating active T-lymphocytes, preventing activation of inactive T-lymphocytes by stimulation of the IL-2 receptor and possibly causing down regulation of IL-2 receptor expression [51,52]. This allows DZM to specifically target the active lymphocytes, leaving the immune system otherwise intact. This is consistent with our results of higher average absolute lymphocytes in the DZM group. DZM has also been genetically engineered to contain 90\% human determinants. This reduces the immunogenicity of the molecule and lengthens its circulating halflife (20 days). An advantage of DZM's long half-life is that T-cell rebound after discontinuation of DZM does not occur. Patients receiving ATG at our center receive a pulse of methylprednisolone at the point of ATG discontinuation to prevent this T-cell rebound. Patients in the ATG group therefore required a significantly higher dose of methylprednisolone compared to the DZM group. Furthermore, because only a fraction of the antibodies from ATG are directed against T-lymphocytes, a large amount of volume (10 mg/kg for 5 to 7 days) must be administered. This extra volume may lead to excess fluid balances which we normally try to avoid after heart transplantation.

A cost analysis revealed that the cost of DZM induction was significantly lower than ATG induction in heart transplant recipients. Total drug cost and hospital ward cost was also less in the DZM group. The use of DZM induction could thus lead to a cost savings of between $\$ 2,000$ and $\$ 3,000$ in some heart transplant recipients.
Our study has demonstrated that DZM was a safe component of induction therapy in heart transplantation. Our study highlights the advantages of DZM, including ease of administration, lower cost, higher lymphocyte count, and freedom from excessive platelet destruction. Both methods of induction therapy worked well with excellent 1-year survival. Daclizumab was a useful induction agent in our immunosuppression protocol for heart transplant recipients.

\section{Competing interests}

This study was funded by an unrestricted research grant from Hoffmann-La Roche. Data collection, analysis, and manuscript preparation was conducted by the investigators in compliance with the protocol and was independent of the sponsor. The authors declare that they have no competing interests.

\section{Authors' contributions}

$J C M, A O$, and MJB participated in research design. JCM, AO, MJB, and SW participated in acquisition of data. EJK, $A O$, and $M J B$, participated in data analysis. JCM, EJK, AO, and MJB participated in writing of the manuscript. All authors read and approved the final manuscript.

\section{Acknowledgements}

The authors wish to thank Dennis L. Modry, MD, Arvind Koshal, MD, Jeffery R. Burton, MD, llene Burton, RN, Wayne J. Tymchak, MD, Karen Doucette, MD, Jutta Preiksaitis, MD, and Phil F. Halloran, MD for their support and assistance with this research.

Presented in part at the 25th Annual Meeting of the International Society of Heart and Lung Transplantation, April 2005, Philadelphia, PA, USA.

Received: 12 March 2014 Accepted: 18 July 2014

Published: 30 July 2014

\section{References}

1. Lund LH, Edwards LB, Kucheryavaya AY, Dipchand Al, Benden C, Christie JD, Dobbels F, Kirk R, Rahmel AO, Yusen RD, Stehlik J, International Society for Heart and Lung Transplantation: The Registry of the International Society 
for Heart and Lung Transplantation: thirtieth official adult heart transplant report-2013; focus theme: age. J Heart Lung Transplant 2013, 32:951-964

2. Miller LW, Naftel DC, Bourge RC, Kirklin JK, Brozenca SC, Jarcho J, Hobbs RE, Mills RM: Infection after heart transplantation: a multi-institutional study. J Heart Lung Transplant 1994, 13:381-393.

3. Abramowicz D, Wissing KM, Broeders N: Induction with anti-CD3 antibodies. Curr Opin Organ Transplant 1999, 4:312-317.

4. Zenapax product monograph. In Roche Pharmaceuticals. 1st edition. Basel, Switzerland: F. Hoffmann - La Roche Ltd.; 1998.

5. Billingham M, Cary NRB, Hammond ME, Kemnitz J, Marboe C, McHallister HA, Snovar DC, Winters GL, Zerbe A: A working formulation for the standardization of nomenclature in the diagnosis of heart and lung rejection: heart rejection study group. J Heart Lung Transplant 1990, 9:587-593.

6. Hamilton A, Norris C, Wensel R, Koshal A: Cost reduction in cardiac surgery. Can J Cardiol 1994, 10:721-727.

7. Sarris GE, Moore KA, Schroeder JS, Hunt SA, Fowler MB, Valantine HB, Vagelos RH, Billingham ME, Oyer PE, Stinson EB: Cardiac transplantation: the Stanford experience in the cyclosporine era. J Thorac Cardiovasc Surg 1994, 108:240-252

8. Asher JF, Wilson CH, Gupta A, Gok MA, Talbot D: Use of daclizumab in preventing delayed graft function in non-heart beating donor kidney transplantation in Newcastle upon Tyne. Transplantationsmedizin: Organ Der Deutschen Transplantationsgesellschaft 2004, 16:96-100.

9. Abou-Jaoude MM, Ghantous I, Almawi WY: Comparison of daclizumab, an interleukin 2 receptor antibody, to anti-thymocyte globulin-Fresenius induction therapy in kidney transplantation. Mol Immunol 2003, 39:1083-1088.

10. Ekberg H, Bäckman L, Tufveson G, Tydén G: Zenapax (daclizumab) reduces the incidence of acute rejection episodes and improves patient survival following renal transplantation. Transplant Proc 1999, 31:267-268.

11. Wilson CH, Brook NR, Gok MA, Asher JF, Nicholson ML, Talbot D: Randomized clinical trial of daclizumab induction and delayed introduction of tacrolimus for recipients of non-heart-beating kidney transplants. Br J Surg 2005, 92:681-687.

12. Nashan B, Light $\mathrm{S}$, Hardie IR, Lin A, Johnson JR: Reduction of acute allograft rejection by daclizumab. Transplantation 1999, 67:110-115.

13. Hengster $P$, Pescovitz MD, Hyatt D, Margreiter R: Cytomegalovirus infections after treatment with daclizumab, an anti IL-2 receptor antibody, for prevention of renal allograft rejection. Transplantation 1999, 68:310-313.

14. Kandus A, Grego K, Bren AF: Prevention of early acute rejection with daclizumab and triple immunosuppression in cadaveric renal allograft recipients. Ther Apyher Dial 2005, 9:262-264

15. Osuna A, Gentil MA, Capdevila L, Cantarell C, Mazuecos A, Pereira P, Rodriguez-Alarra G, Gonzalez-Molina M, Spanish Kidney Transplant of Elderly Donor Study Group: Two doses of daclizumab with delayed introduction of low-dose tacrolimus in elderly recipients of cadaveric renal transplants from donors $>55$ years of age. Transplant Proc 2005, 37:1438-1440.

16. Rostaing L, Cantarovich D, Mourad G, Budde K, Rigotti P, Mariat C, Margreiter R, Capdevilla L, Lang P, Vialtel P, Ortuno-Mirete J, Charpentier B, Legendre C, Sanchez-Plumed J, Oppenheimer F, Kessler M, CARMEN Study Group: Corticosteroid-free immunosuppression with tacrolimus, mycophenolate mofetil, and daclizumab induction in renal transplantation. Transplantation 2005, 79:807-814.

17. Soltero L, Carbajal H, Sarkissian N, Khan AJ, Brennan S, Gonzalez JM, Truong $L D$, Suki WN: A truncated-dose regimen of daclizumab for prevention of acute rejection in kidney transplant recipients: a single-center experience. Transplantation 2004, 78:1560-1563.

18. Poorrezagholi F, Einollahi B, Firoozan A, Nafar M, Yadegari H, Moghaddam SM, Simforoosh N, Basiri A, Farhangi S: Effect of daclizumab (zenapax) on prevention of acute rejection of renal transplantation. Transplant Proc 2003, 35:3735-3736.

19. Bumgardner GL, Hardie I, Johnson RW, Lin A, Nashan B, Pescovitz MD, Ramos E, Vincenti F, Phase III Daclizumab Study Group: Results of 3-year phase III clinical trials with daclizumab prophylaxis for prevention of acute rejection after renal transplantation. Transplantation 2001, 72:839-845.

20. Nair MP, Nampoory MRN, Johny KV, Costandi JN, Abdulhalim M, ElReshaid W, Al-Muzairai I, Ninan VT, Samhan M, Al-Mousawi M: Induction immunosuppression with interleukin-2 receptor antibodies (basiliximab and daclizumab) in renal transplant recipients. Transplant Proc 2001, $33: 2767-2769$.
21. Ekberg H, Bäckman L, Tufveson G, Tydén G, Nashan B, Vincenti F: Daclizumab prevents acute rejection and improves patient survival post transplantation: 1 year pooled analysis. Transpl Int 2000, 13:151-159.

22. Vincenti F: Daclizumab: novel biologic immunoprophylaxis for prevention of acute rejection in renal transplantation. Transplant Proc 1999, 31:2206-2207.

23. Vincenti F, Kirkman R, Light S, Bumgardner G, Pescovitz M, Halloran P, Neylan J, Wilkinson A, Ekberg H, Gaston R, Backman L, Burdick J: Interleukin-2-receptor blockade with daclizumab to prevent acute rejection in renal transplantation. N Engl J Med 1998, 338:161-165.

24. Abou-Jaoude MM, Ghantous I, Najm R, Afif C, Almawi WY: Daclizumab versus anti-thymocyte globulin-fresenius as induction therapy for low-risk kidney transplant recipients. Transplant Proc 2003, 35:2731-2732.

25. Abramowicz D, Vanrenterghem Y, Squifflet JP, Kuypers D, Mourad M, Meurisse M, Wissing M: Efficacy and cardiovascular safety of daclizumab, mycophenolate mofetil, tacrolimus, and early steroid withdrawal in renal transplant recipients: a multicenter, prospective, pilot trial. Clin Transplant 2005, 19:475-482.

26. Meier-Kriesche H-U, Kaza H, Palekar SS, Friedman GS, Mulgaonkar SP, Ojo AO, Kaplan B: The effect of Daclizumab in a high-risk renal transplant population. Clin Transplant 2000, 14:509-513.

27. Ekberg H, Persson NH, Källen R, Gül-Baykurt N: Two doses of daclizumab in conjunction with low-dose cyclosporine, mycophenolate mofetil and Steroids resulted in a low incidence of acute rejection after renal transplantation. Scand J Immunol 2003, 58:670-677.

28. Ciancio G, Burke GW, Suzart K, Roth D, Kupin W, Rosen A, Olson L, Esquenazi $V$, Miller J: Daclizumab induction, tacrolimus, mycophenolate mofetil and steroids as an immunosuppression regimen for primary kidney transplant recipients. Transplantation 2002, 73:1100-1106.

29. Stratta R, Alloway RR, Lo A, Hodge EE, PIVOT Study Group: One-year outcomes in simultaneous kidney-pancreas transplant recipients receiving an alternative dosing regimen of daclizumab. Transplant Proc 2004, 36:1080-1081.

30. Rasaiah SB, Light JA, Sasaki TM, Currier CB: A comparison of daclizumab to ATGAM induction in simultaneous pancreas-kidney transplant recipients on triple maintenance immunosuppression. Clin Transplant 2000, 14:409-412.

31. Boillot O, Mayer DA, Boudjema K, Salizzoni M, Gridelli B, Filipponi F, Trunecka P, Krawczyk M, Clavien PA, Ducerf C, Margarit C, Margreiter R, Pallardo JM: Corticosteroid-free immunosuppression with tacrolimus following induction with daclizumab: a large randomized clinical study. Liver Transp/ 2005, 11:61-67.

32. Innocenti F, Humeres R, Zamboni M, Sanhueza E, Zapata R, Hepp J, Rius M: IL-2 receptor blockers in liver transplantation: initial experience with daclizumab in Chile. Transplant Proc 2003, 35:2520-2521.

33. Fahlke J, Wolff S, Mantke R, Pross M, Weiss G, Buerger T, Lippert H: Staggered immunosuppression with the interleukin-2 receptor antagonist daclizumab combined with tacrolimus, prednisolone, and mycophenolate mofetil after orthotopic liver transplantation: a pilot efficacy and safety study. Transplant Proc 2002, 34:1242-1244.

34. Niemeyer G, Koch M, Light S, Kuse ER, Nashan B: Long-term safety, tolerability and efficacy of daclizumab (zenapax) in a two-dose regimen in liver transplant recipients. Am J Transplant 2002, 2:454-460.

35. Emre S, Gondolesi G, Polat K, Ben-Haim M, Artis T, Fishbein TM, Sheiner PA Kim-Schluger L, Schwartz ME, Miller CM: Use of daclizumab as initial immunosuppression in liver transplant recipients with impaired renal function. Liver Transp/ 2001, 7:220-225.

36. Figueras J, Bernardos A, Prieto M, Gomez M, Rimola A, Ortiz de Urbina J, Cuervas-Mons V, de la Mata M, Dominguez-Granados R: Steroid-free regimen with daclizumab, mycophenolate mofetil, and tacrolimus in liver transplant recipients. Transplant Proc 2002, 34:1511-1513.

37. Mullen J, Oreopoulos A, Lien D, Bentley MJ, Modry DL, Stewart K, Winton TL, Jackson K, Doucette K, Preiksaitis J, Halloran PF: A randomized controlled trial of daclizumab versus anti-thymocyte globulin induction for lung transplantation. J Heart Lung Transplant 2007, 26:504-510.

38. Brock MV, Borja MC, Ferber L, Orens JB, Anzcek RA, Krishnan J, Yang SC, Conte JV: Induction therapy in lung transplantation: a prospective, controlled clinical trial comparing OKT3, anti-thymocyte globulin, and daclizumab. J Heart Lung Transplant 2001, 20:1282-1289.

39. Beniaminovitz A, Itescu S, Lietz K, Donovan M, Burke EM, Groff BD, Edwards N, Mancini DM: Prevention of rejection in cardiac transplantation by blockade of the interleukin-2 receptor with a monoclonal antibody. N Eng J Med 2000, 342:613-619. 
40. Hershberger RE, Starling RC, Eisen $H J$, Bergh $C H$, Kormos RL, Love RB, Van Bakel A, Gordon RD, Popat R, Cockey L, Mamelok RD: Daclizumab to prevent rejection after cardiac transplantation. N Eng J Med 2005, 352:2705-2713.

41. Lietz K, John R, Beniaminovitz A, Burke EM, Suciu-Foca N, Mancini DM, Edwards NM, Itescu S: Interleukin-2 receptor blockade in cardiac transplantation: influence of HLA-DR locus incompatibility on treatment efficacy. Transplantation 2003, 75:781-787.

42. Kobashigawa J, David K, Morris J, Chu AH, Steffen BJ, Gotz VP, Gordon RD: Daclizumab is associated with decreased rejection and no increased mortality in cardiac transplant patients receiving MMF, cyclosporine, and corticosteroids. Transplant Proc 2005, 37:1333-1339.

43. Joyal D, Cantarovich M, Cecere R, Giannetti N: Early experience with two-dose daclizumab in the prevention of acute rejection in cardiac transplantation. Clin Transplant 2004, 18:493-496.

44. Chin C, Pittson S, Luikart H, Bernstein D, Robbins R, Reitz B, Oyer P, Valantine H: Induction therapy for pediatric and adult heart transplantation: comparison between OKT3 and daclizumab. Transplantation 2005, 80:477-481.

45. Carlsen J, Johansen M, Boesgaard S, Andersen CB, Arendrup H, Aldershvilet J, Mortensen SA: Induction therapy after cardiac transplantation: a comparison of anti-thymocyte globulin and daclizumab in the prevention of acute rejection. J Heart Lung Transplant 2005, 24:296-302.

46. Morris JA, Hanson JE, Steffen BJ, Chu AH, Chi-Burris KS, Gotz P, Gordon RD: Daclizumab is associated with decreased rejection and improved patient survival in renal transplant recipients. Clin Transplant 2005, 19:340-345.

47. Bhorade SM, Jordan A, Villanueva J, Yu A, Kramer H, Vigneswaran WT, Garrity ER: Comparison of three tacrolimus-based immunosuppressive regimens in lung transplantation. Am J Transplant 2003, 3:1570-1575.

48. Garrity ER, Villanueva J, Bhorade SM, Husain AN, Vigneswaran WT: Low rate of acute lung allograft rejection after the use of daclizumab, an interleukin 2 receptor antibody. Transplantation 2001, 71:773-777.

49. Sellers MT, McGuire BM, Haustein SV, Bynon JS, Hunt SL, Eckhoff DE: Two-dose daclizumab induction therapy in 209 liver transplants: a single-center analysis. Transplantation 2004, 78:1212-1217.

50. Yan LN, Wang W, Li B, Lu SC, Wen TF, Lin QY, Zeng Y, Cheng NS, Zhao JC, Dai YM: Single-dose daclizumab induction therapy in patients with liver transplantation. World J Gastroenterol 2003, 9:1881-1883.

51. Savo AM, Book BK, Henson S, Hakimi J, Pescovitz MD: Daclizumab rapidly saturates interleukin-2 receptor-alpha (CD25) on lymph node lymphocytes in children. Transplant Proc 1999, 31:1182-1183.

52. Vincenti F, Nashan B, Light S: Daclizumab: outcome of phase III trials and mechanism of action. Transplant Proc 1998, 30:2155-2158.

doi:10.1186/2047-1440-3-14

Cite this article as: Mullen et al: A randomized controlled trial of daclizumab versus anti-thymocyte globulin induction for heart transplantation. Transplantation Research 2014 3:14.

\section{Submit your next manuscript to BioMed Central and take full advantage of:}

- Convenient online submission

- Thorough peer review

- No space constraints or color figure charges

- Immediate publication on acceptance

- Inclusion in PubMed, CAS, Scopus and Google Scholar

- Research which is freely available for redistribution

Submit your manuscript at www.biomedcentral.com/submit
( Biomed Central 